\title{
Relation of Breast Cancer and Malathion Aerial Spraying in Arica, Chile
}

\author{
Relación entre Cáncer Mamario y Aspersiones Aéreas con Malatión en Arica, Chile
}

\author{
Gertrudis Cabello*; Mario Valenzuela-Estrada*; Patricia Siques**; Julio Brito**; Eduardo Parra ${ }^{* * *}$; Ursula Valdivia ${ }^{* * * * *}$; \\ Claudia Lavin ${ }^{* * * * *}$; Alejandra Manríquez ${ }^{* * * * * *}$ \& Alejandro Ortega ${ }^{* * * * * * * *}$
}

CABELlO, G.; VALENZUELA-ESTRADA, M.; SIQUES, P.; BRITO, J.; PARRA, E.; VALDIVIA, U.; LAVIN, C.; MANRÍQUEZ, A. \& ORTEGA, A. Relation of breast cancer and malathion aerial sprinkling in Arica, Chile. Int. J. Morphol., 31(2):640-645, 2013.

SUMMARY: Breast cancer mortality has been increasing in Arica Chile where it has surpassed the national rates 11 times between 1990 and 2010. The city of Arica was sprayed with the organophosphrous pesticide malathion in order to control the Mediterranean fly 33 years ago. Moreover we have demonstrated that a malathion treatment induces the formation of breast carcinomas in Sprague Dowley female rats. The objective of this work was to find a relationship between malathion aerial spraying and the increased mortality rate due to breast cancer that has been observed in Arica in recent years. We extracted city data bases with all breast cancer cases diagnosed from 1995 to 2005 from the Dr. Juan Noe Crevani Hospital of Arica city and Ernesto Torres Hospital of Iquique. The number of patients was 100 in Arica and 58 in Iquique, nearby city that has never been sprayed with malathion which had a similar population than Arica in those years. The statistical analysis of the characteristics of the sample related to breast cancer risk showed that there is no significant difference between women from Arica and from Iquique. Nevertheless the patients with more times of exposure to malathion were 5.7-times more likely to be diagnosed with breast cancer $(\mathrm{OR}=5.7 ; \mathrm{p}<0.02)$. In addition, metastases were found in $30.5 \%$ of the malathion-exposed group and only in $16 \%$ in the group never exposed $(\mathrm{p}<0.05)$. This study suggests that the increase in the mortality rate due to breast cancer occurring in Arica has a significant correlation with the exposure to malathion sprayed over the city more than 30 years ago.

KEY WORDS: Pesticides; Organophosphates; Cholinesterase inhibitor; Metastases; Population health.

\section{INTRODUCTION}

Malignancies are the second most important cause of mortality in Chile. In comparison with other causes, cancer mortality shows an upward trend with increasing mortality rates from 99 to 118 per 100.000 population in the period 1980-1998 (Medina \& Kaempffer, 2001). Also, Chile's mortality rate from breast cancer in women has increased from 12.3/100.000 in 1990 to $15.0 / 100.000$ in 2010, with some fluctuations in between. Arica (a northern city in Chile) shows a strikingly increased mortality over the Chilean mean from $9.4 / 100.000$ in 1990 to $16.8 / 100.000$ in 2010. In fact, during these 21 years, Arica has surpassed 11 times the national rates reaching its highest rate in 2005 with a mortality rate of 18.6/100.000 women (Deis Minsal, 2012).
The factors that might fully account for this increased rate are not completely understood, but in the past some environmental chemicals have been partially implicated in the cancer increase (Perera, 1997). These could explain the epidemiological situation in Arica, since the city was sprayed with malathion for control of the Mediterranean fly the first time 33 years ago. Malathion spraying over the city of Arica, Chile, was performed once a week during two months in years 1979, 1980 and 1987 (Newspaper "La Estrella de Arica” Chile, July 16 1987).

Organophosphorous compounds are primarily absorbed through the skin, the gastrointestinal tract and inhalation

\footnotetext{
Departamento de Biología, Facultad de Ciencias, Universidad de Tarapacá, Arica, Chile.

** Instituto de Estudios de Salud, Universidad Arturo Prat, Iquique, Chile.

*** Facultad de Ciencias, Universidad de Tarapacá, Arica, Chile.

**** Hospital Sótero del Río, Santiago, Chile.

***** Hospital Hernán Henríquez Aravena, Temuco, Chile.

******* Hospital Padre Hurtado, Santiago, Chile.

********* Hospital Dr. Juan Noé Crevani, Arica, Chile.

The research was supported by grant N 4712-05 from Universidad de Tarapacá.
} 
through the respiratory tract. They act as inhibitors of the acetylcholinesterase enzyme responsible for acetylcholine neurotransmitter inhibition (Nigg \& Knaak, 2000). Malathion [S-(1, 2-dicarboethoxyethyl) O, O-dimethyl phosphorodithioate] is a widely used organophosphorous insecticide because of its relatively low toxicity to mammals and high selectivity towards insects compared to other organophosphorous insecticides (Blasiak et al., 1999). It has been used in major eradication programs against insect infestations in metropolitan areas of Florida, Texas and California in USA (Mills \& Yang, 2005). The aerial application of malathion over large urban areas in southern California as part of the 1990 Mediterranean (Medfly) Eradication Program raised concerns over the potential of malathion to cause genetic damage (Flessel et al., 1990). Since then, there has been accumulating evidence of the deleterious effect of malathion. For example, a genotoxic effect in mice fed with cereals treated with malathion has been confirmed (Zayed et al., 1992). Also, it has been found that organophosphorous compounds have mutagenic properties and show organ specific toxicity in relation to the heart, kidneys, lungs, liver and other organs (Tós-Luty et al., 2003). In experimental animals, chromosomal changes including chromosomal aberrations and micronuclei have also been described (Dulout et al., 1982). Cytogenetic effects in human populations have also been observed, such as chromosomal aberrations, micronuclei and sister-chromatid exchanges. These have been observed in floriculturists, greenhouse workers (Bolognesi et al., 2002), and agricultural workers (Pastor et al., 2002).

Previous research in our experimental breast cancer model has demonstrated that epithelial cells in the rat mammary gland underwent a stepwise transformation into malignant cells by exposure to the organophosphorous pesticides parathion and malathion (Cabello et al., 2001). Also, malathion induces increased proliferation cells nuclear antigen, and mutant p53 protein expression on the human breast carcinoma cell line MCF-7, with an increase in the proliferation activity and a decrease in the protection from malignancy (Cabello et al., 2003a). Furthermore, malathion induced a decrease in the expression of the cell adhesion complex E-cadherin/b-catenin, in comparison to controls (Cabello et al., 2003b). Such effects are inhibited by atropine (Cabello et al., 2001, 2003a).

Therefore, gathering further information about the exposure to malathion of Arica inhabitants, and drawing upon data about the increased rate of breast cancer in our previous studies, we designed a research project to prove that the increase in the mortality rate due to breast cancer in Arica could be correlated to the malathion spraying more than 30 years ago. The study was designed by comparing Arica's breast cancer women with a similar breast cancer population never exposed to malathion in the city of Iquique $(300 \mathrm{Km}$ away). The aim of this study was, to determine whether there is a relationship between breast cancer and malathion exposure.

\section{MATERIAL AND METHOD}

Target communities. Arica is a coastal city located in Northern Chile, $60 \mathrm{Km}$ from the border with Peru in a desert area it has two valleys producing fruits and vegetables that are sold mostly in the central area. The presence of fruit flies was detected in 1979, creating problems for the export of fruit from around the country. This is why the decision was made to spray the city with malathion using aircraft. The procedure was performed once a week for two months in 1979, 1980 and 1987. In total Arica city has been sprayed with malathion 24 times.

Iquique is the Chilean city nearest to Arica, it is located $300 \mathrm{Km}$ to the South, also in a desert area, with no valleys. It has never been sprayed with malathion.

Subjects. We retrieved information from city data-bases about all breast cancer cases that were diagnosed from 1995 to 2005 in Arica and in Iquique with a date of birth from January 1st 1946 to December 31 1972 (looking for the ages of greatest susceptibility of the mammary gland, between 7 and 41 years old at the time of fumigation).

Then we reviewed the medical records at the Dr. Juan Noe Crevani Hospital in Arica and the Ernesto Torres Hospital in Iquique. We found 100 women in Arica and 58 in Iquique satisfying these criteria. All women alive and dead fulfilling the above criteria were included. Households were visited, we informed the patient or a close relative (if the patient had died) and invited them to participate in the research. It was possible to locate 33 women in Arica and 25 in Iquique with breast cancer. All of them agreed to participate, and gave their informed consent. To strengthen the results of the studies, for the small number of cases already interviewed, it was considered a case control supplementary study, to compare the general risk factor between women from Arica and Iquique, with their correspondent matched controls. The data registered were:age, smoking status, body mass index, medical history, early menarchea, nuliparity, late menopause, and cancer stage at time of diagnosis. This study was reviewed and approved by the ethics committee of the Universidad de Tarapacá. In relation to years of schooling of the adult population, Arica and Iquique are similar with an average of 10.3 and 10.2 
years respectively, both higher than the national average of 9.8 years (Bonnefoy et al., 2006). In terms of revenue, the 2010 national average was USA $\$ 1620$ per month (considering US $\$ 1=\$ 450$ ) the average in Iquique was USA $\$ 1982$, and in Arica it was USA $\$ 1480$ (33\% lower than Iquique, $p<0.05$ ). This is the only difference found between the populations of the two cities studied (INE, 2010).

Statistical Analysis. The statistical analysis was performed using the STATA 9.0 statistics package. Normality was checked using the KolmogorovSmirnov test. Odds ratios were calculated using a logistic regression. Student's t-test of related samples and Chi2 test were used to find statistical differences among the breast cancer risk factors and metastases distribution in both cities. The significance level was established at p-value $<0.05$.

\section{RESULTS}

In 2005 the total population over 15 years old was 76.186 female in Arica and 101.791 in Iquique. Only the Arica females were exposed to malathion. In Arica 100 cases of breast cancer were diagnosed in that period and in Iquique only 58 . The mortality rate of Arica from 2006 to 2010 is higher than the mortality rate in Iquique in the same period $(\mathrm{p}<0.05$; Fig. 1$)$. $82 \%$ of the women with breast cancer were exposed to malathion in Arica $(\mathrm{n}=27 / 33)$ and only $4 \%$ in Iquique $(n=1 / 25)$ (patient from Iquique living in Arica at the time of malathion spraying). The rate of exposure to malathion in women from Arica and breast cancer was: $84 \%$ for 24 times, $10 \%$ for 16 times and only $6 \%$ for 8 times. Those patients with the highest exposure rates had 5.7 more chances of cancer risk (OR: 5.7; $p<0.02$ ) (Fig. 2). There were no differences of general risk factors associated with breast cancer between women in Arica and Iquique (Table I), nor was there in cancer stage at the time of diagnosis. However, it was observed that patients in Arica (exposed to malathion) had a higher number of metastases $(30.5 \%)$ than the unexposed group $(16 \%, \mathrm{p}<0.05)$ from Iquique.

Fig. 2. Distribution of cancer patients according exposures times to malathion. Of all the women with breast cancer interviewed in Arica, 84\% were exposed during 1979, 1980 and 1987 (8 times every year), altogether 24 times. Patients with more episodes of exposure to malathion were 5.7-times more likely to be diagnosed with breast cancer $(\mathrm{OR}=5.7 ; \mathrm{p}<$ $0.05)$.
Table I. Regression coefficients of women with breast cancer in Arica (exposed to malathion) and Iquique (non exposed to malathion), estimated average logistic regression analysis adjusted for breast cancer risk factors.

\begin{tabular}{lcc}
\hline Risk factor & Regression coefficient & P \\
\hline Age & $-0.44(-1.08,0.19)$ & NS \\
Body mass index & $-0.75(-1.53,0.03)$ & NS \\
Pregnancy & $-0.00(-1.02,1.01)$ & NS \\
Childbirth & $0.85(-0.33,2.04)$ & NS \\
Menarche & $0.44(-0.29,1.16)$ & NS \\
Menopause & $0.00(-0.51,0.52)$ & NS \\
Family history of cancer & $0.81(-0.40,2.02)$ & NS \\
Number of relatives with cancer & $-0,40(-0.82,0.02)$ & NS \\
Smoking status & $-0.25(-1.20,0.71)$ & NS \\
Constant & $-1.32(-5.49,2.84)$ & NS \\
\hline
\end{tabular}

It is noted in the table that the women in the study of Arica and Iquique were not statistically different $p>0.05$ (NS) in relation to risk factors for breast cancer.

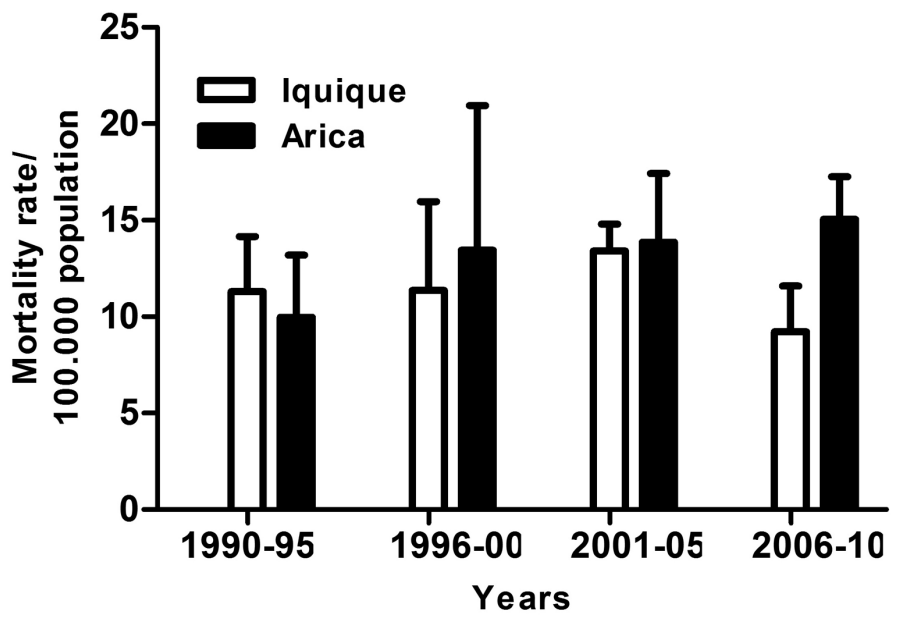

Fig. 1. Breast cancer mortality rate in Iquique and Arica; per 100.000 population, years 1990-2010. The city of Arica was sprayed with malathion once a week during two months in years 1979, 1980 and 1987. The mortality rate of Arica from 2006 to 2010 is higher than the mortality rate in Iquique in the same period $(\mathrm{p}<0.05)$.

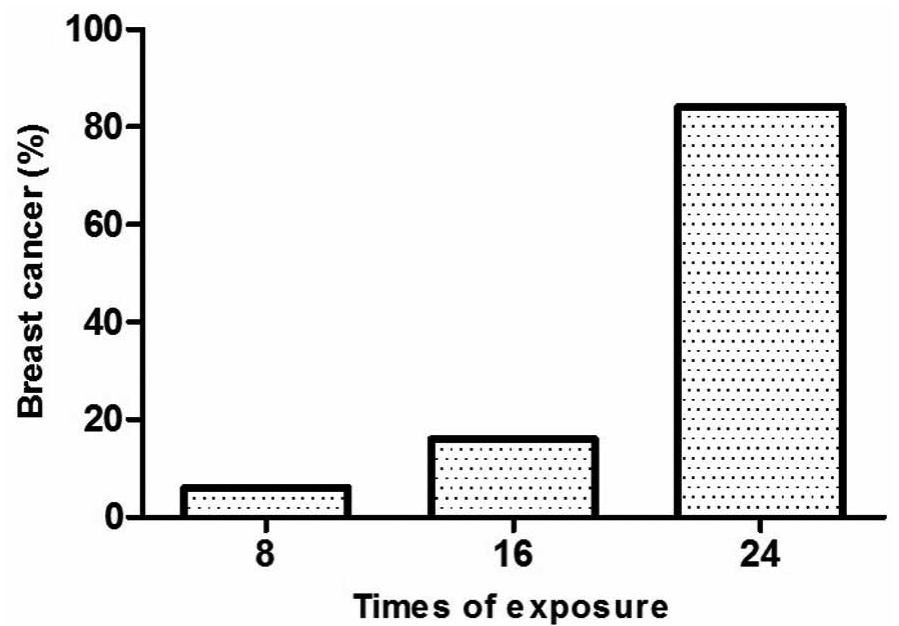




\section{DISCUSSION}

The results of this study suggests that the increase in the mortality rate due to breast cancer found in Arica could have an association with the exposure to malathion sprayed over the city about 30 years ago.

The possible role of pesticides as another risk factor in the etiology of breast cancer is of particular interest in Arica, because of the higher incidence of this cancer than Iquique, especially since both cities have similar epidemiological characteristics in relation to well known risk factors associated with breast cancer. This epidemiological situation is similar to those described by Brody et al. (2004) in the region of Massachusetts, in the USA, called Cape Cod. Cape Cod also has a high historical incidence of breast cancer, preceeded by the extensive use of pesticides. According to the Massachusetts Cancer Registry (MCR) the incidence of breast cancer on Cape Cod is about $20 \%$ higher than in the rest of the state since 1982, when Brody began the MCR. His study also showed that women on Cape Cod between 50-74 years old had a $21 \%$ higher cancer risk than women of other places in Massachusetts where they found the same variables as family history, reproductive history, pharmaceutical hormone use, alcohol, and some aspects relating to the diet (Silent Spring Institute, 1997). This is supported by the work of McKelvey et al. (2004) who demonstrated a high risk of breast cancer associated with years of residence in Cape Cod, independently of other established risk factors. There has been some disagreement with the conclusions of these studies. In the 1980s, the International Agency for Research on Cancer (IARC) postulated that evidence of the mutagenicity of malathion was limited (IARC, 1987), and that the studies both in vitro and in vivo showing cytogenetic changes in humans and other mammals (Windham et al., 1998) have been inconsistent. Nevertheless, with more recent researches (Blasiak et al.), the U.S. Agency for Environmental Protection (EPA, 2000) concluded that there was a suggestive evidence of carcinogenicity, but not enough to rate malathion as a potential human carcinogen, even though some authors have shown what seems to be conclusive research of this carcinogenic effect (Giri et al., 2002). In addition, specific organophosphate insecticides such as chlorpyrifos (Alavanja et al., 2004) and diazinon (Beane Freeman et al., 2005) have shown an increased risk of lung cancer.

Despite, the controversial literature regarding malathion and its probable role as carcinogenic agent, in this study it was possible to show that malathion exposure was the only different risk factor for breast cancer from those already known which could explain the higher mortality and metastases rate seen in Arica. This breast cancer mortality rate found is consistent with the findings of Mills \& Yang who found that malathion with two other pesticides was also associated with an increased risk of breast cancer. To support this association, there is substantial research about the mechanisms involved in pesticides exerting their carcinogenic effects. These include mutations, inhibition of intercellular communication and tight junctions, proliferation of peroxisomes and other promotional activities on liver carcinogenesis (Blair et al., 1991), as well as oxidative stress (Abdollahi et al., 2004). Finally, another study shows the cholinesterase inhibition leading to cell proliferation of epithelial breast cells by cholinergic stimulation (Cabello et al., 2001).

Likewise several others types of tumors in rats in a wide spectrum of organs such as brain, liver, adrenal medulla, lungs and the hematopoietic system have been attributed to malathion (Reuber, 1985). And different studies show good evidence that farmers, who usually are more exposed to pesticides, have a higher risk of non-Hodking's lymphoma than the general population (Hohenadel et al., 2011).

Additional experimental evidence also suggests that malathion or its derivates can induce DNA damage (Blasiak et $a l$.), and that normal human breast cells treated with malathion also induces differential gene expression in genes that may be associated with carcinogenesis. Several other effects on genes by malathion have been shown: increased expression of genes (AKR1C1, AKR1C2, EBBP) involved in steroid and xenobiotic metabolism (Gwinn et al., 2005), genes (CPF, RFC3 and TYMS) involved in DNA replication with a decreased expression and a down regulation, and other several genes up-regulated (cyclins, cyclin D1 and cyclin dependent kinase 4, IGFBP3 and IGFBP5, keratin 18, cHa-ras oncogene, DVL1, HSP 27 MCM2 and TP53) (Calaf \& Roy, 2008).

It should be noted that to find in this study an increased rate of metastases in women with breast cancer in Arica, which could explain the greater mortality rate, is a rather striking and novel result given that the biology of the tumor is a pretty well known phenomenon (Dairkee \& Smith, 1996). Notwithstanding, this study's weakness is in that possible factors influencing these outcomes, such as accessibility, imaging and diagnostic facilities, were not easily assessed. However, the fact that the only difference among both populations in addition to the lower revenue in Arica turned out to be the exposure to high doses of 
malathion, strongly suggest an active role. Therefore, our hypothesis would be consistent with the above literature, and suggests that this phenomenon certainly deserves further research. Moreover, this study suggests that the explanation for the higher breast cancer spreading (metastases), could depend on the ability of malathion to prompt a great variety of tumors or, perhaps, some specific organ induction or susceptibility to be seeded by the circulating cancer cells. These matters, however, are beyond the scope of this study.
This research adds more information that can lead us to think that malathion or organophosphate insecticides play a significant role as another risk factor for breast cancer, as well as a possible intensifying role in the spreading pattern, and ultimately in the mortality rate.

ACKNOWLEDGEMENTS. We thank Dra. Fresia Caba for her assistance in the statistical analysis, Dra. Nandy López and Dr. Robert Swartz for their invaluable help.

CABELlO, G.; VALENZUELA-ESTRADA, M.; SIQUES, P.; BRITO, J.; PARRA, E.; VALDIVIA, U.; LAVIN, C.; MANRÍQUEZ, A. \& ORTEGA, A. Relación entre cáncer mamario y aspersiones aéreas con malatión en Arica, Chile. Int. J. Morphol., 31(2):640-645, 2013.

RESUMEN: La mortalidad por cáncer de mama ha ido aumentando en Arica Chile, donde ha sobrepasado las tasas nacionales 11 veces entre los años 1990 y 2010. La ciudad de Arica recibió aspersiones del pesticida organofosforado malatión, con el fin de controlar la mosca mediterránea, por primera vez hace 33 años. Por otra parte hemos demostrado que un tratamiento con malatión induce la formación de carcinomas mamarios en ratas hembras Sprague Dowley. El objetivo de este trabajo es encontrar una relación entre las aspersiones con malatión y el aumento en la tasa de mortalidad por cáncer de mama que se ha observado en Arica en los últimos años. Se extrajeron de bases de datos, los casos de cáncer mamario diagnosticados entre 1995 y 2005, en los Hospitales Dr. Juan Noé Crevani de Arica y Ernesto Torres de Iquique. El número de pacientes diagnosticados con cáncer de mama fue 100 en Arica y 58 en Iquique, ciudad que nunca fue fumigada con malatión y con una población similar a la de Arica durante esos años. El análisis estadístico de las características de la muestra, en relación a los factores de riesgo de cáncer mamario, mostró que no hay diferencia significativa entre las mujeres de Arica y de Iquique. Sin embargo, las mujeres con mayor tiempo de exposición al malatión fueron 5,7 veces más propensas a ser diagnosticadas con cáncer de mama $(\mathrm{OR}=5,7, \mathrm{p}<0.02)$. Además el 30,5\% del grupo expuesto a malatión presentó metástasis y en el grupo no expuesto sólo el $16 \%$ ( $\mathrm{p}<0.05$ ). Este estudio sugiere que el aumento de la tasa de mortalidad por cáncer de mama que se ha producido en Arica tiene una correlación significativa con la exposición al malatión esparcido sobre la ciudad hace más de 30 años.

PALABRAS CLAVE: Pesticidas; Organofosforados; Inhibidores de colinesterasa; Metástasis; Salud pública.

\section{REFERENCES}

Abdollahi, M.; Mostafalou, S.; Pournourmohammadi, S. \& Shadnia, S. Oxidative stress and cholinesterase inhibition in saliva and plasma of rats following subchronic exposure to malathion. Comp. Biochem. Physiol. C Toxicol. Pharmacol., 137(1):2934, 2004.

Alavanja, M. C.; Dosemeci, M.; Samanic, C.; Lubin, J.; Lynch, C. F.; Knott, C.; et al. Pesticides and lung cancer risk in the agricultural health study cohort. Am. J. Epidemiol., 160(9):87685, 2004.

Beane Freeman, L. E.; Bonner, M. R.; Blair, A.; Hoppin, J. A.; Sandler, D. P.; Lubin, J. H.; et al. Cancer incidence among male pesticide applicators in the agricultural health study cohort exposed to diazinon. Am. J. Epidemiol., 162(11):1070-9, 2005.

Blair, A. An overview of potencial health hazards among farmers from use of pesticides. Surgeon General's Conference on Agricultural Safety and Health, Des Moines, Iowa, 229-42, 1991.

Blasiak, J.; Jaloszynski, P.; Trzeciak, A. \& Szyfter, K. In vitro studies on the genotoxicity of the organophosphorous insecticide malathion and its two analogues. Mutat. Res., 445(2):275-83, 1999.
Bolognesi, C.; Perrone, E. \& Landini, E. Micronucleus monitoring of a floriculturist population from western Liguria, Italy. Mutagenesis, 17(5):391-7, 2002.

Brody, J. G.; Aschengrau, A.; McKelvey, W.; Rudel, R. A.; Swartz, C. H. \& Kennedy, T. Breast cancer risk and historical exposure to pesticides from wide-area applications assessed with GIS. Environ. Health Perspect., 112(8):889-97, 2004.

Bonnefoy, J.; Elacqua, G.; González, S. \& Brunner, J. J. Capital humano en la Región de Tarapacá. Arica, Universidad de Tarapacá, 2006.

Cabello, G.; Valenzuela, M.; Vilaxa, A.; Duran, V.; Rudolph, I.; Hrepic, N.; et al. A rat mammary tumor model induced by organophosphorous pesticides parathion and malathion, possibly through acethylcholinesterase inhibition. Environ. Health Perspect., 109(5):471-9, 2001.

Cabello, G.; Juarranz, A.; Botella, L. M. \& Calaf, G. Organophosphorous pesticides in breast cancer progression. J. Submicrosc. Cytol. Pathol., 35(1):1-9, 2003a.

Cabello, G.; Galaz, S.; Botella, L. M.; Calaf, G.; Pacheco, M.; 
Stockert, J. C.; et al. The pesticide malathion induces alterations in actin cytoskeleton and in cell adhesion of cultured breast carcinoma cells. Int. J. Oncol., 23(3):697-704, 2003 b.

Calaf, G. M. \& Roy, D. Cancer genes induced by malathion and parathion in the presence of estrogen in breast cells. Int. J. Mol. Med., 21(2):261-8, 2008.

Dairkee, S. H. \& Smith, H. S. Genetic analysis of breast cancer progression. J. Mammary Gland Biol. Neoplasia, 1(2):13951,1996

Deis Minsal (Departamento de Estadística e Información de Salud). Ministerio de Salud de Chile 2012. Available in: http:// deis.minsal.cl/index.asp

Dulout, F. N.; Olivero, O. A.; von Guradze, H. \& Pastori, M. C. Cytogenetic effect of malathion assessed by the micronucleus test. Mutat. Res., 105(6):413-6, 1982 .

EPA (Environmental Protection Agency). Office of Prevention: Pesticides and Toxic Substances. Malathion: revised occupational and residential risk assessment eligibility decisions (RED) document. Washington DC, Environmental Protection Agency, 2000.

Flessel, P.; Quintana, P. J. \& Hooper, K. Genetic toxicity of malathion: a review. Environ. Mol. Mutagen., 22(1):7-17, 1993.

Giri, S.; Prasad, S. B.; Giri, A. \& Sharma, G. D. Genotoxic effects of malathion: an organophosphorus insecticide, using three mammalian bioassays in vivo. Mutat. Res., 514(1-2):223-31, 2002 .

Gwinn, M. R.; Whipley, D. L.; Tennant. L. B. \& Weston, A. Differential gene expression in normal human mammary epithelial cells treated with malathion monitored by DNA microarrays. Environ. Health Perspect., 113(8):1046-51, 2005.

Hohenadel, K.; Harris, S. A.; McLaughlin, J. R. Spinelli, J. J.; Pahwa, P.; Dosman, J. A.; et al. Exposure to multiple pesticides and risk of non-Hodgkin lymphoma in men from six Canadian provinces. Int. J. Environ. Res. Public Health, 8(6):2320-30, 2011.

IARC. International Agency of Research on Cancer: monographs on the evaluation of carcinogenic risks to humans. Overall evaluations of carcinogenicity: an updating of IARC monographs,1-42 (Suppl. 7), 1987.

INE (Instituto Nacional de Estadísticas Chile). Nueva encuesta suplementaria de ingresos, 2010. Available in: http:// www.ine.cl/canales/chile_estadistico/mercado_del_trabajo/ nene/nesi/nesi.php

McKelvey, W.; Brody, J. G.; Aschengrau, A. \& Swartz, C. H. Association between residence on Cape Cod, Massachusetts, and breast cancer. Ann. Epidemiol., 14(2):89-94, 2004.
Medina, E. \& Kaempffer, A. M. Cancer mortality in Chile: epidemiological considerations. Rev. Med. Chil., 129(10):1195202, 2001

Mills, P. K. \& Yang, R. Breast cancer risk in hispanic agricultural workers in California. Int. J. Occup. Environ. Health, 11(2):123-31, 2005

Nigg, H. N. \& Knaak, J. B. Blood cholinesterases as human biomarkers of organophosphorus pesticide exposure. Rev. Envirom. Contam. Toxicol., 163:29-111, 2000.

Pastor, S.; Lucero, L.; Gutiérrez, S.; Durbán, R.; Gomez, C. \& Parron, T. A follow up study on micronucleus frequency in Spanish agricultural workers exposed to pesticides. Mutagenesis, 17(1):79-82, 2002 .

Perera, F. P. Environment and cancer: who are susceptible? Science, 278(5340):1068-73, 1997.

Reuber, M. D. Carcinogenicity and toxicity of malathion and malaoxon. Environ. Res., 37(1):119-53, 1985.

Silent Spring Institute. Cape Cod Breast Cancer and Environment Study: Final Report. Newton, Silent Spring Institute, 1997.

Tós-Luty, S.; Obuchowska-Przebirowska, D.; Latuszynska, J.; Tokarska-Rodak, M. \& Haratym-Maj, A. Dermal and oral toxicity of malathion in rats. Ann. Agric. Environ. Med., 10(1):101-6, 2003.

Windham, G. C.; Titenko-Holland, N.; Osorio, A. M.; Gettner, S.; Reinisch, F.; Haas, R.; et al. Genetic monitoring of malathionexposed agricultural workers. Am. J. Ind. Med., 33(2):164-74, 1998.

Zayed, S. M.; Farghaly, M. \& Mostafa, I. Y. Bioavailability to rats and toxicological potential in mice of bond residues of malathion in beans. J. Environ. Sci. Health B., 27(4):341-6, 1992.

\author{
Dirección para correspondencia: \\ Dra. Gertrudis Cabello \\ Departamento de Biología \\ Facultad de Ciencias \\ Universidad de Tarapacá \\ Velásquez 1775 \\ Arica \\ CHILE \\ Email: gcabello@uta.cl \\ gertrudis.cabello@gmail.com
}

Received: 02-01-2013

Accepted: 07-04-2013 